\title{
Phytochemical Investigation Study of Curcuma Caesia Roxb Different Geographical Regions (Delhi and Orissa) of India
}

\author{
Maram Ranemma ${ }^{1}$ and S. Karnakar Reddy ${ }^{2}$ \\ ${ }^{1}$ Research Scholar, Cytogenetics and molecular biology laboratory, Department of Botany, Osmania University. \\ Hyderabad, Telangana-500007. \\ ${ }^{2}$ Associate Professor, Department of Botany, Osmania University. Hyderabad, Telangana-500007.
}

\begin{abstract}
Curcuma caesia is commonly known as kali haldi and it belongs to the family Zingiberaceae. This herb is available throughout North-East, central India, Papi Hills of East Godavari, West Godavari and Andhra Pradesh. In the traditional system of medicine, fresh and dried rhizomes of Curcuma caesia Roxb are used in treating leucoderma, asthma, tumours, piles, bronchitis, bruises, etc. The aim of this study was to evaluate phytochemical constituent of Curcuma caesia Roxb. In this study it was investigated that carbohydrates, proteins, starch, amino acids, steroids glycosides, flavonoids, alkaloids, tannins, phenols, and resins were tested in Curcuma caesia. This article brings to light the major active components present in Curcuma caesia two different geographical regions (Delhi and Orissa) of India. Separation of the rhizome from the plant cut it into small pieces and washed two or three times under tap water, kept the rhizom under shaded dry and collects the fine powder the help of motor pistil.Soxhlet the extraction used for the fine powder completely dissolving in organic solvent like methanol and chloroform by condensation method. The present study will be helpful for the phytochemists and pharmacologists for the identification of new phytochemical compounds.
\end{abstract}

Keywords: Phytochemical analysis, geographical regions, soxhlet extraction, Curcuma caesia Roxb and secondary metabolites.

\section{Introduction}

Curcuma caesia Roxb. Common name: Black turmeric is an important medicinal plant belonging to Zingiberaceae family. Black turmeric is native to North-East and Central India, this is also found in Bangladesh as a wild species. The rhizomes of black turmeric have a high economical importance owing to its putative medicinal properties. Rhizome of this plant is useful in treating several diseases like piles, leprosy, bronchitis, asthma, cancer, epilepsy, fever wounds, impotency, fertility tooth ache and vomiting etc. Presently this plant is considered to be a threatened species since natural habitat is destroying widely through several human activities such as over exploitation of black turmeric for traditional medicine purposes, industrialization, urbanization etc. In Madhya Pradesh, the plant is regarded as very auspicious and is stated that a person who possess it will never experience shortage of cereals and food.The rhizomes of the plant are aromatic in nature .The inner part of the rhizome is bluish-black in colour and emits a characteristic sweet smell, due to presence of essential oil (Pandey and chowdhary, 2003). Traditionally, the rhizomes of Curcuma caesia Roxb. are used in treating leucoderma, asthma, tumours, piles, bronchitis etc. The paste is applied on bruises, contusions and rheumatic pains in Manipur (Sarangathem and Haokip, 2010)5 .In Arunachal Pradesh, Adi tribes use decoction of fresh rhizome as anti-diarrhoetic. The Khamti tribe of Lohit district applied the paste of fresh rhizome in case of snake and scorpion bite Kagyung et al. 2010; Tag et al. 2007). Curcuma caesia Roxb is widely used in Ayurvedic, Unani and Siddhha Herbal System. It is also recommended for treating diabetes, high cholesterol, abdominal pains, menstrual disorder, Wounds, eczema, psoriasis, Jaundice, Inflammations, Cancerous Symptoms and as a blood purifying activit.

\section{Materials And Methods}

Collection of the rhizome from medicinally popular genotypes of Curcuma caesia and raising the plants in the garden.Collected the rhizome from different places of India(Orissa and Delhi geographical regions) and Grown in the Botanical garden, Department of Botany, Osmania University, Hyderabad.

\section{Preparation of rhizome extracts}

The ground rhizome material were extracts with methanol and chloroform using soxhlet apparatus for $18 \mathrm{hrs}$ and solvent was evaporated to dryness at constant temperature of $72^{\circ} \mathrm{C}$ at reduced pressure. The residues were weighed and stored at $4^{\circ} \mathrm{C}$ temperature until use for phytochemical screening.

Screening of phytochemicals

About $20 \mathrm{~g}$ of the rhizome powder was soaked in $100 \mathrm{ml}$ methanol solvent and chloroform and Incubated for 48 hrs and then filtered using Whattman No.1 filter paper and methanol extract and chloroform were obtained. 
Phytochemical analysis was carried out using methanol plant extract using standard methods (Amarsingham et al. 1964; Harborne, 1973; Raaman, 2006; Karhikeyan et al. 2009). The detailed and systematic pharmacognostic and phytochemical evaluations of Curcuma caesia gives valuable information in order to produce standardized finished herbal products.

\section{Identification tests for phytochemical constituents}

The tests were performed to find out the presence of active chemical constituents such as carbohydrates, proteins,starch,amino acids ,steroids glycosides, flavonoids, alkaloids, tannins, saponins,phenols, resins by the following procedure. Phytochemical analysis was carried out for all the extracts using standard methods.

1. Test for Carbohydrate

a) Molisch's test: For two ml test solution added two drops of the molisch's reagent (a solution of $\alpha$ - napthol in $95 \%$ ethanol). The solution is then poured slowly in to a tube containing two ml of concentrated sulphuric acid so that two layers form. Purple to reddish violet colour at the junction of two layers indicates the presence of carbohydrate.

b) Benedict's test: To $5 \mathrm{ml}$ of benedict's reagent few $\mathrm{ml}$ of plant extract was added and boiled for $2 \mathrm{~min}$, cooled. The formations of red precipitate indicate the presence of carbohydrates.

\section{Test for proteins}

It is used to determine the presence of peptide bonds in protein. To $3 \mathrm{ml}$ of test sample add $3 \% \mathrm{NaOH}$ and few drops of $1 \% \mathrm{CuSO} 4$. The solution turns from blue to violet (purple) or to pink .Show the presence of protein.

\section{Test for Starch}

Mix $3 \mathrm{ml}$ test solution and few drops of dilute Iodine solution. Blue colour appears. It disappears on boiling and reappears on cooling.

\section{Test for Aminoacids}

To $5 \mathrm{ml}$ of test sample solution add few drops of $40 \% \mathrm{NaOH}$ and $10 \%$ lead acetate boiled the solution formation of black precipitate it show the presence of amino acids.

\section{Test for Steroids}

To $2 \mathrm{ml}$ of extract add $2 \mathrm{ml}$ chloroform and $2 \mathrm{ml}$ conc. $\mathrm{H}_{2} \mathrm{SO}_{4}$ shake well; chloroform 1 layer show greenish yellow fluorescence.

\section{Test for Glycosides}

To the solution of the extract add glacial acetic acid, few drops 5\% ferric chloride and concentrated sulphuric acid are added, and observed for a reddish brown colorations at the junction of two layers and the bluish green colour in the upper layer.

\section{Test for Flavanoid}

To $4 \mathrm{ml}$ of extract add $1.5 \mathrm{ml} \mathrm{50 \%} \mathrm{methanol} \mathrm{solution.} \mathrm{The} \mathrm{solution} \mathrm{was} \mathrm{warmed} \mathrm{and} \mathrm{metal} \mathrm{magnesium} \mathrm{was}$ added. To this solution, 5- 6 drops of concentrated HCL was added, red colour was observed for flavonoids and orange colour for flavones.

\section{Test for Alkaloid}

To $0.5 \mathrm{~g}$ of each extract add $5 \mathrm{ml}$ of $1 \%$ aqueous HCL and kept in water bath; $1 \mathrm{ml}$ of the filtrates to be treated with mayer's reagent (Potassium Mercuric Iodide). Formations of a yellow coloured precipitate indicate the presence of alkaloids.

\section{Test for Tannins}

To $0.5 \mathrm{ml}$ of extract solution, $1 \mathrm{ml}$ of water and 1-2 drops of ferric chloride solution was added. Blue colour was observed for Gallic tannins and green black for catecholic tannins.

\section{Test for saponins}

To $1 \mathrm{ml}$ extract add $2 \mathrm{ml}$ distilled water and shake it. Persistent foam was observed.

11. Test for Phenols:

To the crude extract $2 \mathrm{ml}$ of $2 \%$ ferric chloride solution was added and black coloration was observed for the presence of phenols.

\section{Test for Resins:}

To the crude extract acetone was added and whole solution was poured into the distilled water, turbidity indicates the presence of resins in the extract.

Results:

\section{Result And Discussion}

This study has revealed the presence of medicinal chemical constituents. Important phytochemicals considered as active medicinal phytochemicals such terpenoids, reducing sugar, flavonoids and alkaloids were present in the samples. Epidemiologic studies recommend that coronary heart disease is opposed by dietary flavonoids. Tannins have amazing stringent properties. They are known to hasten the healing wounds and 
Phytochemical investigation study of Curcuma caesia Roxb different geographical regions (Delhi ..

inflamed mucous membranes. Flavonoids are also present in two selected medicinal plants as a potent water soluble antioxidant and free radical scavenger, which prevent oxidative cell damage and also have strong anticancer activity (Rio et al. 1997; Salah et al. 1995). It also helps in managing diabetes induced oxidative stress. Terpenoids have been found to be useful in the prevention and therapy of several diseases, including cancer. Terpenoids are also known to possess antimicrobial, antifungal antiparasitic, antiviral, anti-allergenic, antispasmodic, anti hyperglycemic, anti-inflammatory and immunomodulatory, properties (Rabi and Bishayee, 2009; Wagner and Elmadfa, 2003).

Numerous studies have confirmed that saponins possess the unique property of precipitating and coagulating red blood cells and steroids are responsible for cholesterol reducing properties (Okwu, 2004; Sodipo et al. 2000). Steroids also help in regulating the immune response (Shah et al. 2009). Alkaloids represent a class which affects the central nervous system, reduces appetite and behaves as diuretic (United States Department of Agriculture, 2010).

Table-1: Phytochemical screening of methanol \& chloroform of Curcuma caesia rhizome extract (Delhi Geographical region)

\begin{tabular}{|l|c|c|}
\hline \multicolumn{1}{|c|}{ Test } & methanol & Chloroform \\
\hline Carbohydrates & + & + \\
\hline Proteins & + & + \\
\hline Starch & - & - \\
\hline Amino acids & + & + \\
\hline Steroids & - & + \\
\hline Glycosides & + & - \\
\hline Flavonoids & + & - \\
\hline Alkaloids & + & + \\
\hline Tannins & + & - \\
\hline Saponins & - & + \\
\hline Phenols & + & - \\
\hline Resins & + & + \\
\hline
\end{tabular}

$(+)$ : Presence and (-) : Absence of metabolites in the methanol and chloroform rhizome extract

Table-2: Phytochemical screening of methanol \& chloroform of Curcuma caesia Roxb rhizome extract (Orissa Geographical region)

\begin{tabular}{|l|c|c|}
\hline \multicolumn{1}{|c|}{ Test } & methanol & Chloroform \\
\hline Carbohydrates & + & + \\
\hline Proteins & + & + \\
\hline Starch & - & - \\
\hline Amino acids & + & + \\
\hline Steroids & - & + \\
\hline Glycosides & + & + \\
\hline Flavonoids & - & - \\
\hline Alkaloids & + & - \\
\hline Tannins & + & - \\
\hline Saponins & - & - \\
\hline Phenols & + & - \\
\hline Resins & + & - \\
\hline
\end{tabular}

(+): Presence and (-): Absence of metabolites in the methanol and chloroform rhizome extract

\section{Discussion}

The selection of crude plant extracts for screening programs has the potential of being more successful in initial steps than the screening of pure compounds isolated from natural products. The plant extract are the source of the secondary metabolites i.e., alkaloids, flavonoids, terpenoids, tannins etc. The phytochemical analysis of the Curcuma caesia is important and has in both commercial interest research institutes and pharmaceuticals companies for the manufacturing of the new drugs for treatment of various diseases. Curcuma caesia has medicinal value the presence of these major constituents (Paliwal et al. 2012). Thus we hope that the important phytochemical properties identified by our study in the local plant of different geographical regions (Delhi and Orissa) of India will be helpful to develop new compounds for health benefits.

Curcuma caesia (Delhi Geographical region) Present phytochemical study done by two organic solvents (methanol and chloroform).In methanolic crude extract carbohydrates, proteins amino acids, glycosides, Flavonoids, Alkaloids, Tanins, phenols, resins are present. Steroids, saponins starch are absent. (In methanolic crude extract shows phenols are present in highest amount, resins and flavonoids are present moderate while steroids and saponins are poor in methanolic.)(table: 1). Curcuma caesia Roxb (Orissa Geographical region) Present phytochemical study done by two organic solvents (methanol and chloroform).In methonolic crude 
Phytochemical investigation study of Curcuma caesia Roxb different geographical regions (Delhi ..

extract carbohydrates, proteins amino acids, glycosides, Alkaloids, Tanins, phenols, resins are present. Starches, Steroids, saponins, flavonoids are absent. In methanolic crude extract shows phenols are present in highest amount, resins and Alkaloids are present moderate while steroids and saponins are poor in methanolic crude extract.lin chloroform crude extract of Curcuma caesia (Delhi Geographical region) carbohydrates, proteins, amino acids, steroids, glycosides, tannins, phenols are present and starch, alkaloids, flavoniods, saponins, resins are absent. In chloroform extract of Curcuma caesia (Orissa geographical region) carbohydrates, proteins, amino acids, steroids, glycosides are present and starch, flavonoids, alkaloids, tannins, saponins, phenols, resins are absent. In the present investigation methanol extract of Curcuma caesia (Delhi Geographical region) shows the presence of nine phytochemicals, and chloroform extracts contains only seven phytocemicals, (Table :1). Curcuma caesia Roxb (Orissa Geographical region) methanol Extract having eight phytochemicals whereas Chloroform extract contain five secondary metabolites from the rhizomes of Curcuma caesia Roxb Linn (table: 2). From above studies Methanolic extract contains more number of Phytochemicals whereas Chloroform extract shows less number of phytochemicals.

\section{Acknowledgment}

My heartiest thanks to UGC (BSR-RFSMS), New Delhi, for providing fellowship and giving financial support my research work and UGC-UPA FAR subsidiary project Financial support in the form of contigent grant.

\section{References}

[1]. Amarsingham, P.P. et al. 1964. Phytochemical survey of Malaya, Part3. Alkaloids and saponins. Econ. Taxonomic Bot., 18: 270 278 .

[2]. Arulmozhi, D.K. et al. 2006. Preliminary mechanistic studies on the smooth muscle relaxant effect of hydroacloholic extract of Curcuma caesia J. Herbal Pharmacother., 6(3/4). Methods: A guide to modern. caesia. Flavour Fragr J., 18: $463-5$.

[3]. Comparison of Curcuma caesia Roxb. With other Commonly Used Curcuma Species by HPTLC journal of Pharmacognosy and Phytochemistry 2013; 2 (4): 126-131.

[4]. Crude extract of the leaf of Adhatoda vasica.L. Int. J. GreePharm., 3(1): 78- 80.

[5]. Curcuma caesia roxb. And it's medicinal uses: a review (International journal of research in pharmacy and chemistry) Sonjit Das, ProdyutMondal and Md. Kamaruz Zaman. Department of Pharmaceutical Sciences, Dibrugarh University, Assam-786 004.

[6]. Harborne, J.B. 1973.phytochemica methods: A guide to modern techniques of plant analysis champmann \& hall.London. 279Pp.

[7]. International Journal of Science, Environment ISSN 2278-3687 (O) and Technology, Vol. 2, No 4, 2013 , 634 - 641 Received June 27, 2013 Published August 2, 2013635

[8]. Kagyung, R. et al. 2010. Ethnomedicinal plant used for gastrointestinal diseases by Adi tribe of Dehang-Debang biosphere reserve in Arunachal Pradesh. J. Trad. Know, 9 (3): 496-501.

[9]. Karthikeyan, A. et al. 2009. Preliminary phytochemical and antibacterial screening of Okwu, D.E. 2004. Phytochemicals and vitamin content of indigenous spices of southeastern Nigeria. J. Sustain Agric. Environ., 6: 30- 37.

[10]. Paliwal, P. et al. 2012. Pharmacognostic parameters for evaluation of the rhizomes of Curcuma caesia. J. Adv. Pharm. Tech. Res., 2: $56-61$

[11]. Pandey, A.K., Chowdhary, A.R. 2003. Volatile constituents of rhizome oil of Curcuma R.S. Sawant and A.G. Godghate. Evaluation of phytochemical constituent in conventional and non conventional species of curcuma, international research journal of pharmacy,issn no:2230-8407.

[12]. Raaman, N. 2006. Phtochemical techniques, New India Publishing Agency, New Delhi.

[13]. Rabi, T., Bishayee, A. 2009. Terpenoids and breast cancer chemoprevention. Breast Cancer Res. Treat., 115: 223 -239.

[14]. Rio, D.A. et al. 1997. Uses and properties of citrus flavonoids. J. Agric. Food Chem., 45: 4505- 4515.

[15]. Salah, N. et al. 1995. Polyphenolic flavonoids as scavenger of aqueous phase radicals as chain breaking antioxidant. Arch. Biochem. Broph. 2: 339- 46.

[16]. Sarangthem, K., Haokip, M.J. 2010. Bioactive components in Curcuma caesia Roxb. grown in Manipur. Bioscan, 5(1): $113-115$.

[17]. Sasikumar, B. 2005. Genetic resource of Curcuma: diversity, characterization and utilization. Plant Genet. Resource, 3: 230251.

[18]. Sastri, B.N. 1950. The wealth of India raw material. Manager, Government of India Press, New Delhi. Pp. 2.

[19]. Shah, B.A. et al. 2009. Boswellic acids: a group of medicinally important compounds. Nat. Prod. Rep., 26: 72-89.

[20]. Sodipo, O.A., et al. 2000. Studies on certain characteristics of extracts of bark of Pansinystalia macruceras (K schemp) pierre Exbeille. Global J. Pure Appl.Sci., 6: 83- 87.

[21]. Tag, H. et al. 2007. Antiinflammatory plant used by Khamti tribes of Lohit d istrict in Arunachal Pradesh. Natural Product Radiat., 4(6): $340-343$

[22]. United States Department of Agriculture, 2010. Center for nutrition policy and promotion. Dietary Guidelines for Americans. National Academy Press, Washington, DC, USA.

[23]. Wagner, K.H., Elmadfa, I. 2003. Biological relevance of terpenoids: Overview focusing on mono-di and tetraterpenes. Ann. Nutr. Metab, 47: 95- 106. 